\title{
Level of user satisfaction on the Facebook library
}

\author{
Dessy Harisanty
}

\section{Introduction}

Facebook has become a very popular social network in recent years. The ease of internet access provided by various cellular providers makes Facebook more popular than other social networking sites. The number of users in Indonesia (only the USA and India have more users) is large, and in the past six months, the number of Facebook users in Indonesia increased by about $3,889,180$. Indonesia represents 17.72 per cent of the total population or about 45 million people (Tri Wahono, kompas.com, Wednesday, February 1, 2012).

Facebook has penetrated all aspects of academia and can facilitate the interaction between users and librarians, without having to be bound by distance and geographical barriers. Facebook is chosen as a medium to meet the needs of information users to interact directly (real time); for example, Facebook chats, tags photos, blogs, games and status updates are assessed more frequently than other media.

The existence of Facebook helps libraries spread information quickly and accurately. In college, the library is a technical implementation unit which together with other units collect, select, process, care and serve information resources to the academic community in general (Depdiknas, 1994). In fact, the utilization of Facebook in the libraries of state universities in Surabaya area is still very limited. One of the libraries that utilize the media is the library of Universitas Airlangga (Unair) with the initial goal to convey information to users quickly and accurately. The media was formed in 2009, and until 2018, it is managed by the field of public relations (PR) library Unair. Unair Library receives information from the media and provides information related to activities at home and abroad. Based on the phenomenon, the researchers are interested to examine the level of user satisfaction of Facebook library Unair.

\section{Discussion}

Users often face difficulty in finding information and from the intensity of following updates from the Facebook library. Respondents of a survey had moments when it is difficult to find information by asking friends as much as 61 per cent. Friends are considered able to reduce the uncertainty that a person feels when needing information, as McCaskill (2015) discloses that information needs are met with recommendations and opinions from friends, because a high trust in friends outweighs the trust in search engines. Almost 25 per cent of students tried to find information on their own. Group discussions accounted for 8 per cent and 6 per cent did not even try to find information in any way.

Each respondent had personal characteristics when they linked to the library's Facebook page. We found that users with introverted personal types used the Facebook library more than the extrovert personal types. Widyastuti (2014) explains that Facebook users tend to have introverted nature and express their emotions on Facebook and are uncomfortable in expressing themselves.

The results of this survey follow those of Effendy (2000) of the need for social integration Facebook libraries often also inform the latest news so that the information submitted is up to date. Our Facebook library not only provides information about the library but also updates the latest entertainment such as movies to be played. Most respondents knew of Facebook before from their own browsing and friends. Most respondents did not experience any barriers in accessing the Facebook library as it was already a tool they were familiar with.
The majority of respondents visit the Facebook library one to two times a week with a visit less than $15 \mathrm{~min}$. Some users spend less than $10 \mathrm{~h} /$ month. Only a small percentage of respondents use Facebook for about 10-40 h/month. Most users access Facebook to meet their information needs. According to respondents, the quality of information posted on the Unair Library wall is relevant to their needs. Many respondents stated that the availability of information on the Facebook library is complete, although some respondents stated that there is still information they need that is not available, such as information on the latest collections and current issues in the library field.

Respondents felt there were many benefits to become a Facebook library member of Unair, which is getting information about the activities that the library will do (18.1 per cent), getting a lot of information about the library (16.2 per cent) and making lots of friends (14, 2 per cent), and a small proportion of respondents stated that they can broaden general knowledge (13.1 per cent) and exchange information (12.8 per cent). Respondents responded positively to the various attributes displayed in the Facebook Library Unair, ranging from the color and arrangement of Facebook interface, the availability of space large enough for faculty managers Unair library to up load the information, including the content of information that is in accordance with the needs of respondents. Facebook is widely used by libraries because of its ability to connect libraries with users who may not know the resources and services that exist. Tamar Sadeh (2007) argues that applying Facebook presence is essential to remain relevant and to meet user expectations, especially with younger users .

Satisfaction with social media will be obtained when the social media user becomes an active and not a passive user. Satisfaction with social media can be identified based on 
surveillance, diversion/entertainment, individual identity and social relationship. Supervision is that social media is able to provide information about something that may affect something or will help someone do or achieve something (Aharony, 2012). The second statement about the Facebook library is to support academic activities within the category of satisfaction. This is in accordance with the results of research conducted by Chanlin and $\mathrm{Su}$ (2015), who revealed that Facebook library can be used to share information related to academics. The use of social media such as Facebook as one of the tools for library promotion. Travel with research conducted by Phillips (2011) that social media is used for library promotion to post activities either from the activities of the library itself or from other communities so that it can be attended by library users.

\section{Final remarks}

Respondents were satisfied with the Facebook Library Unair as a media surveillance, social relationships, individual identity and diversion/ entertainment. Facebook was used to find out the ins and outs of libraries, socialize, search for more information trends, obtain information on the latest news, exchange information and look for information related to hobbies. Most use the Facebook library for information needs. Respondents responded positively to the various attributes displayed in the Facebook Library Unair, ranging from the color and arrangement of the interface, the availability of space large enough for faculty managers of Unair library to upload information, including the content of information that is in accordance with the needs of respondents. Based on our experiences and survey, the library keeps updating the information, and our experiences can be a recommendation for other libraries to develop their service-oriented users.

\section{REFERENCES}

Aharony, N. (2012), "Facebook use in librariescebook use in libra: an exploratory analysis", Vol. 64 No. 4, pp. 358-372, available at: https://doi.org/10.1108/00012531211244725

Chanlin, L. and Su, Y. (2015), “Assessing information needs and interaction needs for library Facebook", Procedia - Social and Behavioral Sciences, Vol. 191, pp. 319-322, available at: https://doi.org/10.1016/j. sbspro.2015.04.703

Depdiknas (1994), Buku Pedoman Perpustakaan Perguruan Tinggi, Dirjen Dikti, Edisi Kedua, Depdiknas, Jakarta.

Effendy, O.U. (2000), Ilmu, Teori Dan Filsafat Komunikasi, Citra Aditya Bakti, Bandung.

McCaskill, A. (2015), "Recommendations from friends remain most credible form of advertising among consumers; branded websites are the Second-Highest-Rated form", available at: www.nielsen.com/ug/en/ press-room/2015/recommendations-from-fri ends-remain-most-credible-form-of-advertis ing.html

Phillips, N.K. (2011), "Academic library use of Facebook: building relationships with students", The Journal of Academic Librarianship, Vol. 37 No. 6, pp. 512-522, available at: https://doi.org/ 10.1016/j.acalib.2011.07.008

\section{FURTHER READING}

Fischer, L.D. (2012), "Facebook use in relation to gender, introversion-extroversion, and sense of belonging among college students", Disertation, Northeastern University, Boston.

Grgic, I.H. (2013), “Croatian school libraries on Facebook: meeting the needs of young library users", New Library World, Vol. 114 No. 9, pp. 416-427, available at: https://doi.org/10.1108/NLW-01-20130010

Harris, A., Lessick, S., Harris, A. and Lessick, S. (2007), "Libraries get personal: Facebook applications, google gadgets, and MySpace profiles", Library Hi Tech News, Vol. 24 No. 8, pp. 30-32, available at: https:// doi.org/10.1108/07419050710836018

Lampe, C., Ellison, N. and Steinfield, C. (2007), "The benefits of Facebook friends: social capital and college students' use of online social network sites", Journal of Computer-Mediated Communication, Vol. 12 No. 4, pp. 1143-1168.

Pempek, T.A., Yermolayeva, Y.A. and Calvert, S.L. (2009), “College students' social networking experiences on Facebook", Journal of Applied Developmental Psychology, Vol. 30 No. 3, pp. 227-238.

Subrahmanyam, K., Reich, S.M., Waechter, N. and Espinoza, G. (2008), "Online and offline social networks: use of social networking sites by emerging adults", Journal of Applied Developmental Psychology, Vol. 29 No. 6, pp. 420-433.

Dessy Harisanty (dessy.harisanty@ vokasi.unair.ac.id) is based at the Department of Library Studies, Faculty of Vocational Studies Universitas Airlangga, 